\title{
Proton balance of plants: physiological, agronomical and ecological implications
}

\author{
G. R. Findenegg, M. L. van Beusichem and W. G. Keltjens \\ Department of Soil Science and Plant Nutrition, Agricultural University, De \\ Dreijen 3, 6703 BC Wageningen, Netherlands
}

Key words: acid rain, ammonium, ionic balance of plants, lime-induced chlorosis, nitrate, organic acids, $\mathrm{pH}$ of the rooting medium, plant growth, soil acidification

\section{Introduction}

Internal $\mathrm{pH}$ and internal nutrient concentrations of plants are both essential for optimal development and growth. Internal $\mathrm{pH}$ can be kept constant against an external variation of more than $5 \mathrm{pH}$ units in different soils, even more than the variation in the concentration of most plant nutrients which usually do not vary by more than 2 or 3 orders of magnitude.

Problems involved in maintaining a constant internal $\mathrm{pH}$ are different from the problems involved in maintaining constant internal nutrient levels. Firstly, considerable amounts of $\mathrm{H}^{+}$ions may be produced as a side-product of plant metabolism. For instance, $1 \mathrm{H}^{+}$ion is produced per $\mathrm{NH}_{4}^{+}$ion during its assimilation and $1 \mathrm{H}^{+}$ion is consumend per $\mathrm{NO}_{3}^{-}$ion during its reduction (Dijkshoorn, 1962, 1973). Secondly, uptake of nutrients by plants can be adjusted freely, the only limitations being their availability in the soil. On the other hand, uptake of $\mathrm{H}^{+}$ions is determined by the uptake of the other nutrients: for the maintenance of electrical neutrality between the plant and its environment, $\mathrm{H}^{+}$ion uptake is equivalent to the difference between the uptake of nutrient anions and cations.

The most important mechanism available for compensating excess or deficient $\mathrm{H}^{+}$ions within the plant is the synthesis and the degradation of organic acids. Synthesis of organic acids from neutral precursors (e.g. carbohydrates) delivers $\mathrm{H}^{+}$ ions, whilst their degradation proceeds at the expense of $\mathrm{H}^{+}$ions. The activities of some enzymes involved in metabolism of malic acid in plants are regulated by the $\mathrm{pH}$ of the cytoplasm in such a way that any deviation of cytoplasmic $\mathrm{pH}$ is corrected immediately by changes in the level of malate (Raven \& Smith, 1976).

In this paper plant-borne deviations from optimal $\mathrm{pH}$ inside and outside the plant will be discussed together with their consequences for growth. Several compartments will be considered with respect to $\mathrm{H}^{+}$ion imbalances, viz the rhizosphere, the 'free space' of the root, the xylem and phloem sap, and the root and shoot cells. Most emphasis will be given to the effects of $\mathrm{NO}_{3}^{-}$and $\mathrm{NH}_{4}^{+}$nutrition. 


\section{Physiological aspects}

\section{The $\mathrm{H}^{+}$ion balance of nitrate-grown plants}

When all nitrogen is taken up by a plant in the form of nitrate, the total $\mathrm{H}^{+}$ion balance is either neutral or negative, depending on plant species species (Dijkshoorn, 1958; van Egmond, 1975). The latter case is called an 'acidic uptake' pattern (van Egmond, 1975) referring to the excess of inorganic acid anions like $\mathrm{NO}_{3}^{-}, \mathrm{SO}_{4}^{2-}$, $\mathrm{H}_{2} \mathrm{PO}_{4}^{-}$, and $\mathrm{Cl}^{-}$taken up. Evidently, an acidic uptake pattern will result in an alkalinization of the rhizosphere.

A variable part of the $\mathrm{NO}_{3}^{-}$taken up is assimilated in the root, depending on plant species (Pate, 1973) and other factors. The greater the percentage of $\mathrm{NO}_{3}^{-} \mathrm{re}-$ duced in the shoot of a plant species, the greater will be the storage of carboxylates in the shoot and the smaller the acidity of the uptake (Keltjens, 1982). This observation suggests that plants are not able to transfer a significant part of the alkalinity created during $\mathrm{NO}_{3}^{-}$reduction (or of the organic acids produced for its neutralization) from the shoot to the root. According to the 'Ben Zioni-Lips' model carboxylates produced in the leaves could be transferred to the roots via the phloem, together with $\mathrm{K}$ ions (Ben-Zioni et al., 1970). Much effort has been made in order to establish whether such a mechanism operates in living plants (e.g. Kirkby \& Armstrong, 1980; Breteler \& Hänisch ten Cate, 1978). Experiments with Ricinus communis, where not only xylem but also phloem sap can be collected and analysed, do not indicate a major contribution of such a mechanism in the neutralization management of this plant species (van Beusichem et al., 1985).

\section{The $\mathrm{H}^{+}$ion balance of plants using $\mathrm{NH}_{4}^{+}$or symbiotically fixed nitrogen}

When $\mathrm{NH}_{4}^{+}$is the sole nitrogen species taken up by plants, the uptake pattern is always strongly alkaline. $\mathrm{NH}_{4}^{+}$ions are assimilated almost quantitatively within the roots (Raven \& Smith, 1976; van Beusichem \& Neeteson, 1982). The $\mathrm{H}^{+}$ions liberated there can easily leave the plant in exchange with further nutrient cations taken up. The organic acid anions found in the shoot of $\mathrm{NH}_{4}^{+}$-grown plants should have been produced in the roots in order to function as counter-ions for the inorganic cation escess in the ascending xylem sap. Cation concentrations in leaves are often much lower in $\mathrm{NH}_{4}^{+}$-grown compared to $\mathrm{NO}_{3}^{-}$-grown plants (e.g. Breteler, 1973). This may partly be explained by the anion deficit in the xylem sap, when no $\mathrm{NO}_{3}^{-}$is present (Arnozis \& Findenegg, 1986).

When nitrogen is taken up by plants in a non-ionic form, uptake of the remaining nutrient cations is generally higher than that of mineral anions (van Beusichem, 1984). In the xylem sap of pea plants considerable amounts of aspartic acid anions were found when the plants used symbiotically fixed nitrogen. Aspartate neutralized about $80 \%$ of the inorganic cation excess in the xylem sap (van Beusichem, 1983). Root-shoot transfer of nitrogen in the form of organic anions may enable the plant to transport sufficient cations to the shoot, when $\mathrm{NO}_{3}^{-}$is absent.

Recirculation of nutrients in plants

A general problem in all these studies is the uncertainty about the extent to which 
ionic components are retranslocated between shoot and root. Some authors measured very high retranslocation rates (e.g. Simpson et al., 1982), others obtained much lower figures (Keltjens et al., 1986). It seems that these published differences are not only due to the different plant species or growth conditions chosen, but also to the experimental methods used and especially to their interpretation. The composition of the collected xylem and/or phloem sap not necessarily represents the composition of the sap in the living plant. When, on the other hand, isotopes are used in whole-plant recirculation studies the root and shoot of the plant may be either considered as being 'totally mixed', i.e. with a uniform specific activity all over the organs. Alternatively, it may be considered as being not mixed at all, i.e. that the entering specific activity should equal the specific activity leaving the organ (Keltjens, 1981). The truth apparently lies somewhere between these extremes but appropriate models for describing such a situation are lacking.

\section{Agronomical and ecological aspects}

\section{' $\mathrm{H}^{+}$ion status' of plants}

Under normal circumstances the internal $\mathrm{pH}$ will remain in balance. Only under extreme growth conditions the coordination of the reactions involving release or consumption of $\mathrm{H}^{+}$ions may get impaired or exhausted and growth depressions may result.

For monitoring disturbances of the intracellular $\mathrm{H}^{+}$ion balance of crops, a parameter would be useful which reliably indicates the ' $\mathrm{H}^{+}$ion status' of plants. It has been proposed to use the excess inorganic cation over inorganic anion charge concentration ('C-A') for this purpose (de Wit et al., 1963). The C-A value is a measure for the organic acid concentration in the tissue. Several growth experiments with different small-grain crops have indicated, that maximum yields can only be obtained within a rather narrow range of C-A values (de Wit et al., 1963). This would indicate that these plants react very sensitive to even small shifts in their $\mathrm{H}^{+}$ion balance. However, in these experiments the only source of variation was the concentration ratio of either the cations or the anions in the nutrient solution. More recent growth experiments, where the $\mathrm{H}^{+}$ion balance was affected by variation of external pH and nitrogen source (Jungk, 1970; Findenegg et al., 1982) allowed the conclusion that the range of cation excess in the tissue which can be tolerated without yield depression is much broader than was originally believed.

\section{Interactions between external nitrogen source and $\mathrm{pH}$ on plant growth}

Growth experiments with nutrient solutions have shown, that a $\mathrm{pH}$ of 4.0 and lower affects growth of many plant species severely (Islam et al., 1980). Such results are important, especially for intensive soil-less cultivation systems.

$\mathrm{NH}_{4}^{+}$nutrition results in an excretion of $\mathrm{H}^{+}$ions. Thus, when plants are grown on solid substrates, $\mathrm{NH}_{4}^{+}$nutrition will aggravate negative effects of external acidity on plant growth because the $\mathrm{pH}$ of the rhizosphere gets lower than the $\mathrm{pH}$ in the bulk substrate.

Acidification of the rhizosphere is a major reason for the negative effect of $\mathrm{NH}_{4}^{+}$ 
Table 1. Effect of the $\mathrm{pH}$ of the nutrient solution on relative growth of several grain, legume and other crop species. The $\mathrm{pH}$ has been kept constant by continuous titration with acid or base. Dry matter yield at $\mathrm{pH} 6.0$ was set to $100 \%$ in two separate growth experiments with $\mathrm{NO}_{3}^{-}$or $\mathrm{NH}_{4}^{+}$as sole source of nitrogen. Relative growth with $\mathrm{NH}_{4}^{+}$compared to $\mathrm{NO}_{3}^{-}$nitrogen (last column) has been established in a third experiment. Nutrient solutions: Arnozis \& Findenegg (1986).

\begin{tabular}{|c|c|c|c|c|c|c|c|c|c|}
\hline \multirow[t]{3}{*}{ Crop } & \multicolumn{8}{|c|}{ Relative dry matter yield in $\%(\mathrm{pH} 6$ is 100$)$} & \multirow{3}{*}{$\begin{array}{l}\mathrm{NH}_{4}^{+} / \mathrm{NO}^{-} \\
\mathrm{pH} 6\end{array}$} \\
\hline & \multicolumn{4}{|l|}{$\mathrm{NH}_{4}^{+}$} & \multicolumn{4}{|l|}{$\mathrm{NO}_{3}^{-}$} & \\
\hline & pH 4 & pH 5 & pH 6 & $\mathrm{pH} 7$ & $\mathrm{pH} 4$ & $\mathrm{pH} 5$ & $\mathrm{pH} 6$ & $\mathrm{pH} 7$ & \\
\hline oats & 144 & 132 & 100 & 66 & 113 & 117 & 100 & 99 & 71 \\
\hline maize & 106 & 108 & 100 & 78 & 120 & 116 & 100 & 94 & 93 \\
\hline barley & 72 & 92 & 100 & 32 & 125 & 87 & 100 & 82 & 129 \\
\hline sorghum & 71 & 64 & 100 & 45 & 107 & 113 & 100 & 98 & 118 \\
\hline soyabean & 60 & 94 & 100 & 98 & 94 & 95 & 100 & 113 & 102 \\
\hline pea & 57 & 94 & 100 & 84 & 105 & 121 & 100 & 139 & 94 \\
\hline lupin & 92 & 76 & 100 & 137 & 92 & 93 & 100 & 166 & 94 \\
\hline sunflower & 19 & 88 & 100 & 77 & 99 & 85 & 100 & 116 & 99 \\
\hline flax & 20 & 83 & 100 & 53 & 71 & 98 & 100 & 101 & 72 \\
\hline carrot & - & 48 & 100 & 95 & 55 & 115 & 100 & 111 & 63 \\
\hline spinach & - & 94 & 100 & 82 & 17 & 94 & 100 & 135 & 8 \\
\hline beet & 25 & 70 & 100 & 51 & 55 & 94 & 100 & 149 & 45 \\
\hline
\end{tabular}

on plant growth (Barker et al., 1966; Karim \& Vlamis, 1962).

Interactions between external nitrogen source and $\mathrm{pH}$ are observed even when plants are grown on nutrient solution at constant $\mathrm{pH}$ (Table 1). Even under these conditions the root cells of $\mathrm{NH}_{4}^{+}$-grown plants might be exposed to a lower $\mathrm{pH}$ than with $\mathrm{NO}_{3}^{-}$-grown plants, because the intercellular $\mathrm{pH}$ of the root (in the 'free space') may be lowered. We confirmed the classic results of Pirschle (1931) showing that negative effects of $\mathrm{NH}_{4}^{+}$on plant growth are observed not only at low but also at high $\mathrm{pH}$ values. The effect of $\mathrm{pH}$ on the dissociation of $\mathrm{NH}_{4}^{+}$and the resulting increase of the phytotoxic $\mathrm{NH}_{3}$ at high $\mathrm{pH}$ may explain this phenomenon.

\section{Nitrogen nutrition and $\mathrm{H}^{+}$ion balance of soil-grown plants}

When plants are grown on soil the direct effects of soil and rhizosphere $\mathrm{pH}$ on plant roots will always be overshadowed by secondary $\mathrm{pH}$ effects. Rhizosphere $\mathrm{pH}$ can affect the growth and the development of crops then in various ways. It can influence fungal infection of grains (Smiley, 1979), infection of legumes by Rhizobium spp. (Munns, 1978; van Beusichem \& Langelaan, 1984), the solubilization of not readily soluble phosphate fertilizers (Bekele et al., 1983), and aluminium toxicity (Foy et al., 1965).

Unexpectedly, not all of the plant species respond negatively to aluminium under influence of $\mathrm{NH}_{4}^{+}$nitrogen. In some species the negative effect of $\mathrm{NH}_{4}^{+}$nutrition is even alleviated by Al ions (Kotze et al., 1977; Rorison, 1985). Probably in these cases $\mathrm{Al}$ ions in the rhizosphere protect cell membranes against the $\mathrm{H}^{+}$ion stress introduced by $\mathrm{NH}_{4}^{+}$. A protection of plant root cells against $\mathrm{H}^{+}$ions is well-known for 
$\mathrm{Ca}^{2+}$ ions (Moore, 1974), but $\mathrm{Al}$ ions are also effective in this respect (Viets, 1944).

$\mathrm{NH}_{4}^{+}$from fertilizers will be nitrified sooner or later in the soil, so that plant roots are exposed to a mixture of both $\mathrm{NO}_{3}^{-}$and $\mathrm{NH}_{4}^{+}$nitrogen. Under these conditions the $\mathrm{NO}_{3}^{-} / \mathrm{NH}_{4}^{+}$uptake ratio - and in consequence the $\mathrm{H}^{+}$ion excretion and the $\mathrm{pH}$ of the rhizosphere - can vary considerably. The $\mathrm{NO}_{3}^{-} / \mathrm{NH}_{4}^{+}$uptake ratio is influenced by the $\mathrm{NO}_{3}^{-} / \mathrm{NH}_{4}^{+}$concentration ratio (Warncke \& Barber, 1973) and the $\mathrm{pH}$ (Marcus-Wyner, 1983) of the soil solution, but also by the plant species (Ikeda \& Osawa, 1981).

As outlined above, plants making use of symbiotically fixed nitrogen, such as legumes, display a slightly alkaline uptake pattern. It would be interesting to know whether the often observed spectacular decreases of soil $\mathrm{pH}$ measured in pot experiments (van Beusichem, 1981, 1982; Aguilar \& van Diest, 1981; Mengel \& Steffens, 1982) can be reproduced in the field.

The $\mathrm{pH}$ difference between the rhizosphere and the bulk medium may be estimated on the basis of the $\mathrm{H}^{+}$ion excretion, the buffer capacity of the soil, and the mass flow of water towards the root surface (Nye, 1981).

An important question is whether the $\mathrm{pH}$ of the rhizosphere can be quantitatively predicted on the basis of the nutrient uptake pattern. Excretion of organic acids by plant roots may abolish such a simple relationship. An excretion of citric acid by the roots of lupins is part of a mechanism for the mobilization of phosphates from the soil (Gardner et al., 1983). In contrast, the acidification of the rhizosphere measured with another P-efficient plant species, rape, has been reported to be due to a shift in the nutrient uptake pattern (Hedley et al., 1982).

\section{Lime-induced chlorosis}

Many plant species when grown on alkaline soils suffer from 'lime-induced chlorosis', a nutritional disorder of major economic importance. Apparent symptoms are an increased level of organic acids, especially citrate (Wallace et al., 1976) and an increased $\mathrm{pH}$ of the tissue (Cain, 1954) and apparent signs of Fe deficiency (Wallace et al., 1976). Fe concentration in the plant are sometimes low, but often normal or even increased. Apparently, only a small 'active' fraction of total Fe in the plant is available for metabolic functions, while the major portion is precipitated as insoluble Fe compounds (Wallace et al., 1976).

$\mathrm{HCO}_{3}^{-}$in the soil solution is an important factor in evoking lime-induced chlorosis (Boxma, 1972). $\mathrm{HCO}_{3}^{-}$may originate from $\mathrm{CO}_{2}$ evolved in the respiration of roots or soil microorganisms, or from calcareous soil particles. In practice, $\mathrm{HCO}_{3}^{-}$ levels of soils are much more dependent on their alkalinity and gas diffusivity than on respiratory activity.

External $\mathrm{HCO}_{3}^{-}$may penetrate root cells and increase internal $\mathrm{pH}$. Recently increased cytoplasmic $\mathrm{pH}$ values have been shown in root cells of chlorotic sunflower plants (Kolesch et al., 1984). Plants will try to decrease $\mathrm{pH}$ again by increasing the synthesis of organic acids. The capacity to keep Fe in the 'active' state may be impaired at the increased internal $\mathrm{pH}$. This suggestion should be considered in connection with the $\mathrm{pH}$ dependency of the Fe-III reduction at cell membranes (Sijmons et al., 1984). 
Lime-induced chlorosis of peanut has been successfully treated by leaf sprayings with diluted sulphuric acid (Dungarwal et al., 1974). It is more likely that in these experiments sulphuric acid has corrected the disturbed $\mathrm{H}^{+}$ion balance of the plants rather than having affected their Fe metabolism via a positive sulphur-ion interaction (Dungarwal et al., 1974).

Formerly, only those plant species which lower the $\mathrm{pH}$ in their rhizosphere by making the nutrient uptake balance more alkaline (van Egmond \& Aktas, 1977) have been considered as being 'Fe-efficient'. It now becomes evident that grasses, which do not show such a reaction, develop another strategy to take up sufficient $\mathrm{Fe}$ from the soil, based on the excretion of Fe chelators (Römheld \& Marschner, 1986).

\section{Effect of soil acidification and $\mathrm{NH}_{3}$ depositions on the vegetation}

The effect of acid depositions on forest vegetations and other ecosystems has attained much attention in the last years. The soils in the Netherlands are exposed to an acidification potential of about $6000 \mathrm{~mol} \mathrm{H}^{+}$per ha and annum. These depositions coincidently provide the soil with a considerable amount of nitrogen: about 20 $\mathrm{kg} / \mathrm{ha}$ as $\mathrm{NO}_{\mathrm{x}}$ and about $30 \mathrm{~kg} / \mathrm{ha}$ as $\mathrm{NH}_{4}^{+}$per annum (van Aalst, 1984).

Acid depositions lead to adverse effects on the vegetation. Especially the vitality of trees is impaired through browning and loss of needles. The way these symptoms are accomplished is not totally understood. Both direct effects of air-contaminating components and indirect effects via changes in soil characteristics may play a role. The latter is strongly supported by the apparent gradual accumulation of the stress: although the air contamination did not increase substantially during the last years, the vitality of the trees has decreased considerably in the same period.

It is well-documented that affected needles have drastically lowered contents of several nutrients, especially of $\mathrm{Mg}$ and $\mathrm{K}$ (Krause et al., 1984). Such an effect has often been recognized to result from growth at a too low soil $\mathrm{pH}$, another argument for the involvement of soil $\mathrm{pH}$ in the observed damage syndrome.

The increased supply of $\mathrm{NH}_{4}^{+}$and its increased uptake by the plants will result in damage of the vegetation irrespective whether it is nitrified in the soil or not. In the first case the bulk soil will be acidified by the nitrification process, in the latter case the acidification will be due to the nutrient uptake pattern and thus be confined to the rhizosphere.

The complex interrelationships between the supply of $\mathrm{NO}_{3}^{-}$and $\mathrm{NH}_{4}^{+}$, nitrification, soil acidification, and $\mathrm{Al}$ toxicity, mentioned above, may lead to variable responses with different plant species. Further research should concentrate on the behaviour of the most relevant species.

\section{Conclusions}

The net uptake or net extrusion of $\mathrm{H}^{+}$ions by plant roots is dominated by the form of nitrogen nutrition. It is unknown how the metabolic reactions affecting the internal $\mathrm{H}^{+}$ion balance are coordinated in the different plant compartments. However, responses of plants to toxic or deficient levels of $\mathrm{H}^{+}$ions cannot be adequately un- 
derstood without a thorough knowledge of their $\mathrm{H}^{+}$ion balance which in turn is determined by the regulation of the uptake and by the metabolism of the nitrogen species used.

Direct and indirect $\mathrm{H}^{+}$ion stress reactions are of importance when soils with extreme $\mathrm{pH}$ values are used for agricultural purposes, but also when optimalization of yields is intended by means of soil-less cultivation systems. Finally, knowledge of the $\mathrm{H}^{+}$ion balances of individual plants may be helpful in understanding their stress resistance and competitive ability in natural habitats.

\section{References}

Aalst, R. M. van, 1984. Depositie van verzurende stoffen in Nederland. In: Zure regen. Oorzaken, effecten en beleid, pp. 66-70. Proceedings van het Symposium in 's-Hertogenbosch, Pudoc, Wageningen.

Aguilar, S. A. \& A. van Diest, 1981. Rock-phosphate mobilization induced by the alkaline uptake pattern of legumes utilizing symbiotically fixed nitrogen. Plant \& Soil 61: 27-42.

Arnozis, P. A. \& G. R. Findenegg, 1986. Electrical charge balance in the xylem sap of beet and sorghum plants grown with either $\mathrm{NO}_{3}$ or $\mathrm{NH}_{4}$ nitrogen. Journal of Plant Physiology (in press).

Barker, A. V., R. J. Volk \& W. A. Jackson, 1966. Growth and nitrogen distribution patterns in bean plants (Phaseolus vulgaris L.) subjected to ammonium nutrition. I. Effects of carbonates and acidity control. Proceedings of the Soil Science Society of America 30: 228-232.

Bekele, T., B. J. Cino, P. A. I. Ehlert, A. A. van der Maas \& A. van Diest, 1983. An evaluation of plant-borne factors promoting the solubilization of alkaline rock phosphorus. Plant \& Soil 75: 361-378.

Ben-Zioni, A., Y. Vaadia \& S. H. Lips, 1970. Correlations between nitrate reduction, protein synthesis and malate accumulation. Physiologia Plantarum 23: 1039-1047.

Beusichem, M. L. van, 1981. Nutrient absorption by pea plants during dinitrogen fixation. 1. Comparison with nitrate nutrition. Netherlands Journal of Agricultural Science 29: 259-272.

Beusichem, M. L. van, 1982. Nutrient absorption by pea plants during dinitrogen fixation. 2. Effects of ambient acidity and temperature. Netherlands Journal of Agricultural Science 30: 85-97.

Beusichem, M. L. van, 1983. Xylary charge distribution and nitrogen transport in Pisum sativum L. during dinitrogen fixation or nitrate nutrition. Zeitschrift für Pflanzenphysiologie 109: 449-458.

Beusichem, M. L. van, 1984. Non-ionic nitrogen nutrition of plants. Nutrient uptake and assimilation and proton extrusion during utilization of urea or symbiotically fixed nitrogen. Thesis, Agricultural University, Wageningen.

Beusichem, M. L. van \& J. G. Langelaan, 1984. Nitrogen accumulation in nodulated and non-nodulated pea plants, grown in sandy soil at different acidities. Communications in Soil Science and Plant Analysis 15 : 493-506.

Beusichem, M. L. van \& J. J. Neeteson, 1982. Urea nutrition of young maize and sugar-beet plants with emphasis on ionic balance and vascular transport of nitrogenous compounds. Netherlands Journal of Agriculture Science 30: 317-330.

Beusichem, M. L. van, R. Baas, E. A. Kirkby \& J. A. Nelemans, 1985. Intracellular pH regulation during $\mathrm{NO}_{3}$-assimilation in shoot and roots of Ricinus communis. Plant Physiology 78: 768-773.

Boxma, R., 1972. Bicarbonate as the most important soil factor in lime-induced chlorosis in the Netherlands. Plant \& Soil 37: 233-243.

Breteler, H., 1973. A comparison between ammonium and nitrate nutrition of young sugar-beet plants grown in nutrient solutions at constant acidity. 1. Production of dry matter, ionic balance and chemical composition. Netherlands Journal of Agricultural Science 21: 227-244.

Breteler, H. \& Ch. H. Hänisch ten Cate, 1978. Ionic balance of root-shoot nitrate transfer in dwarf bean. Physiologia Plantarum 42: 53-56.

Cain, J. C., 1954. Blueberry chlorosis in relation to leaf $\mathrm{pH}$ and mineral composition. Proceedings of the American Society for Horticultural Science 64: 61-70. 


\section{G. R. FINDENEGG, M. L. VAN BEUSICHEM AND W. G. KELTJENS}

Dijkshoorn, W., 1958. Nitrate accumulation, nitrogen balance and cation-anion ratio during regrowth of perennial ryegrass. Netherlands Journal of Agricultural Science 6: 211-221.

Dijkshoorn, W., 1962. Metabolic regulation of the alkaline effect of nitrate utilization in plants. Nature 194: 165-167.

Dijkshoorn, W., 1973. Organic acids, and their role in ion uptake. In: G. W. Butler \& R. W. Bailey (Eds.), Chemistry and biochemistry of herbage, Vol. 2, p. 163-188. Academic Press, London and New York.

Dungarwal, H. S., P. N. Mathur \& H. G. Singh, 1974. Effect of foilar sprays of sulphuric acid with and without elemental sulphur in the prevention of chlorosis in peanut (Arachis hypogaea L.). Communications in Soil Science and Plant Analysis 5: 331-339.

Egmond, F. van, 1975. The ionic balance of the sugar-beet plant. Agricultural Research Report 832. Pudoc, Wageningen.

Egmond, F. van \& M. Aktas, 1977. Iron nutritional aspects of the ionic balance of plants. Plant \& Soil 48: $685-703$.

Findenegg, G. R., M. Salihu \& N. A. Ali, 1982. Internal self-regulation of $\mathbf{H}^{+}$-ion concentration in acid damaged and healthy plants of Sorghum bicolor (L.) Moench. In: A. Scaife (Ed.), Plant nutrition 1982, Vol. 1, p. 174-179. Proceedings 9th International Colloquium (Conventry, UK).

Foy, C. D., G. R. Burns, J. C. Brown \& A. L. Fleming, 1965. Differential aluminium tolerance of two wheat varieties associated with plant-induced changes around their roots. Soil Science Society of America Proceedings 29: 64-67.

Gardner, W. K. D. A. Barber \& D. G. Parbery, 1983. The acquisition of phosphorus by Lupinus albus L. III. The probable mechanism by which phosphorus movement in the soil/root interface is enhanced. Plant \& Soil 70: 107-124.

Hedley, M. J., P. H. Nye \& R. E. White, 1982. Plant induced changes in the rhizosphere of rape (Brassica napus var. Emerald) seedlings. II. Origin of the $\mathrm{pH}$ changes. New Phytologist 91 : 31-44.

Ikeda, H. \& T. Osawa, 1981. Nitrate- and ammonium-N absorption by vegetables from nutrient solution containing ammonium nitrate and the resultant change of solution $\mathrm{pH}$. Journal of the Japanese Society for Horticultural Science 50: 225-230.

Islam, A. K. M. S., D. G. Edwards \& C. J. Asher, 1980. pH optima for crop growth. Results of a flowing solution culture experiment with six species. Plant \& Soil 54: 339-357.

Jungk, A., 1970. Wechselwirkungen zwischen Stickstoffkonzentration $\left(\mathrm{NH}_{4}, \mathrm{NH}_{4} \mathrm{NO}_{3}\right.$ und $\left.\mathrm{NO}_{3}\right)$ und pH der Nährlösung auf Wuchs und Ionenhaushalt von Tomatenpflanzen. Gartenbauwissenschaft 35: 13-28.

Karim, A. Q. M. B. \& J. Vlamis, 1962. Comparative study of the effects of ammonium and nitrate nitrogen in the nutrition of rice. Plant \& Soil 16: 32-41.

Keltjens, W. G., 1981. Absorption and transport of nutrient cations and anions in maize roots. Plant \& Soil 63 : $39-46$.

Keltjens, W. G. 1982. Nitrogen metabolism and K-recirculation in plants. In: A. Scaife (Ed.), Plant nutrition 1982, Vol. 1, p. 283-287. Proceedings 9th International Colloquium (Coventry, UK).

Keltjens, W. G., J. W. Nieuwenhuis \& J. A. Nelemans, 1986. Nitrogen retranslocation in plants of maize, lupin and cocklebur. Plant \& Soil 91: 323-327.

Kirkby, E. A. \& M. J. Armstrong, 1980. Nitrate uptake by roots as regulated by nitrate assimilation in the shoot of castor oil plants. Plant Physiology 65: 286-290.

Krause, G. H. M., B. Prinz \& K.-D. Jung, 1984. Untersuchungen zur Aufklärung immisionsbedingter Waldschäden in der Bundesrepublik Deutschland. In: Zure regen. Oorzaken, effecten en beleid, $\mathrm{p}$. 104-112. Proceedings van het Symposium in 's-Hertogenbosch. Pudoc, Wageningen.

Kolesch, H., M. Oktay \& W. Höfner, 1984. Effect of iron chlorosis-inducing factors on the pH of the cytoplasm of sunflower (Helianthus annuus). Plant \& Soil 82: 215-221.

Kotze, W. A. G., C. B. Shear \& M. Faust, 1977. Effect of nitrogen source and aluminium in nutrient solution on the growth and mineral nutrition of apple and peach seedlings. Journal of the American Society for Horticultural Science 102: 279-282.

Marcus-Wyner, L., 1983. Influence of ambient acidity on the absorption of $\mathrm{NO}_{3}$ and $\mathrm{HN}_{4}$ by tomato plants. Journal of Plant Nutrition 6: 657-666.

Mengel, K. \& D. Steffens, 1982. Beziehung zwischen Kationen/Anionen-Aufnahme von Rotklee und Protonenabscheidung der Wurzeln. Zeitschrift für Pflanzenernährung und Bodenkunde 145: 229-236. 
Moore, D. P., 1974. Physiological effects of pH on roots. In: E. W. Carson (Ed.), The plant root and its environment, p. 135-151. The University Press of Virgina.

Munns, D. N., 1978. Soil acidity and nodulation. In: C. S. Andrews \& E. J. Kamprath (Eds.), Mineral nutrition of legumes in tropical and subtropical soils, p. 247-263. CSIRO, Melbourne.

Nye, P. H., 1981. Changes of $\mathrm{pH}$ across the rhizosphere induced by roots. Plant \& Soil 61: 7-26.

Pate, J. S., 1973. Uptake, assimilation and transport of nitrogen compounds by plants. Soil Biology and Biochemistry 5: 109-119.

Pirschle, K., 1931. Nitrate und Ammoniumsalze als Stickstoffquellen für höhere Pflanzen bei konstanter Wasserstoffionenkonzentration. III. Planta 14: 583-676.

Raven, J. A. \& F. A. Smith, 1976. Nitrogen assimilation and transport in vascular land plants in relation to intracellular $\mathrm{pH}$ regulation. New Phytologist 75: 415-431.

Römheld, V. \& H. Marschner, 1986. Evidence for a specific uptake system for iron phytosiderophores in roots of grasses. Plant Physiology 80: 175-180.

Rorison, I. H., 1985. Nitrogen source and the tolerance of Deschampsia flexuosa, Holcus lanatus and Bromus erectus to aluminium during seedling growth. Journal of Ecology 73: 83-90.

Sijmons, P. C., F. C. Lanfermeijer, A. H. de Boer, H. B. A. Prins \& H. F. Bienfait, 1984. Depolarization of cell membrane potential during trans-plasma membrane electron transfer to extracellular electron acceptors in roots of iron-deficient Phaseolus valguris L. Plant Physiology 76: 943-946.

Simpson, R. J., H. Lambers \& M. J. Dalling, 1982. Translocation of nitrogen in a vegetative wheat plant (Triticum aestivum). Physiologia Plantarum 56: 11-17.

Smiley, R. W., 1979 Wheat rhizosphere $\mathrm{pH}$ and the biological control of take-all. In: J. H. Harley \& R. S. Russel (Eds.), The soil-root interface, p. 329-338. Academic Press, London.

Viets, F. G. Jr., 1944. Calcium and other polyvalent cations as accelerators of ion accumulation by excised barley roots. Plant Physiology 19: 466-480.

Wallace, A., R. A. Wood \& S. M. Soufi, 1976. Cation-anion balance in lime-induced chlorosis. Communications in Soil Science and Plant Analysis 7: 15-26.

Warncke, D. D. \& S. A. Barber, 1973. Ammonium and nitrate uptake by corn (Zea mays L.) as influenced by nitrogen concentration and $\mathrm{NH}_{4}^{+} / \mathrm{NO}_{3}^{-}$ratio. Agronomy Journal 65: 950-953.

Wit, C. T. de, W. Dijkshoorn \& J. C. Noggle, 1963. Ionic balance and growth of plants. Agricultural Research Report 69.15. Pudoc, Wageningen. 